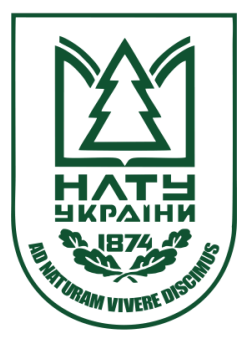

Науковий вісник НлТУ України

Scientific Bulletin of UNFU

https://nv.nltu.edu.ua

https://doi.org/10.15421/40280908

Article received 27.09.2018 p.

Article accepted 25.10.2018 p.

удк 658.[012.32+589]

ISSN 1994-7836 (print)

ISSN 2519-2477 (online)

$@ \bowtie$ Correspondence author

K. O. Doroshkevych

kateryna.o.doroshkevych@lpnu.ua

К. О. Дорошкевич1, М. М. Вороновська', І. З. Салата ${ }^{2}$

${ }^{I}$ Національний університет "Львівська політехніка", м. Львів, Україна

${ }^{2}$ Національна академія сухопутних військ ім. гетьмана Петра Сагайдачного, м. Львів, Украйна

\title{
ОСОБЛИВОСТІ МЕНТОРИНГОВОЇ ДІЯЛЬНОСТІ НА ПІДПРИЄМСТВАХ В УМОВАХ ІННОВАЦІЙНОГО РОЗВИТКУ
}

\begin{abstract}
Досліджено мотиваційні процеси підприємств в умовах інноваційного розвитку, які полягають у стимулюванні творчої активності, креативності працівників та переважанні нематеріальних методів стимулювання над матеріальними; окреслено вплив персоналізованих методів навчання та розвитку персоналу на інноваційну діяльність підприємств. Досліджено методи стимулювання працівників через їх навчання та професійний та особистісний розвиток: коучінг, менторинг, баддинг, супервізію, едвайзинг тощо. Враховуючи переваги та недоліки досліджених методів, у практику мотиваційної діяльності рекомендовано впровадження менторингу як наставницької діяльності, під час якого досвідченіший працівник ділиться знаннями зі своїми колегами протягом певного часу. Особливості менторингової діяльності на підприємствах в умовах інноваційного розвитку поділено на три групи: процесійні особливості, які характеризують процес менторингової діяльності (довготривалість, наявність порядку менторингової діяльності, гнучкість та необхідність усунення бюрократичних процедур, системність), особливості результатів менторингової діяльності (прикладний характер, генерування міжособистісних взаємозв'язків, формування системи матеріальних та нематеріальних стимулів), методологічні особливості (мотивування усіх учасників менторингу, індивідуальний підхід, обмеження та труднощі у визначенні ментора).
\end{abstract}

Ключові слова: мотивування; інноваційна діяльність; наставництво; коучінг.

Вступ. Як відомо, мотивування є важливим елементом у технології управління підприємствами. Як загальна функція менеджменту, мотивування забезпечує спонукання працівників на досягнення особистих цілей та цілей підприємства. Одним із основних завдань, які повинні бути вирішені у процесі мотивування, є формування дієвої системи стимулювання. Зазвичай у практиці управління підприємствами використовують матеріальні (премії, доплати, надбавки та інші грошові винагороди) та нематеріальні стимули (кар'єрний ріст, оголошення подяки, залучення до управління) (Kuzmin, 2003). Зважаючи на цінність грошових і речових винагород для працівників, методи матеріального стимулювання $\epsilon$ більш застосовуваними та результативними у практиці управління вітчизняними підприємствами.

В умовах інноваційної діяльності, що характеризується використанням наукового, технічного і творчого потенціалу працівників підприємств, зростанням обсягів фінансування необхідних науково-дослідних та дослідно-конструкторських робіт, підвищеним рівнем ризику та невизначеності, активізацією креативної діяльності тощо, змінюються пріоритети працівників щодо мотивування. Це проявлясться у тому, що важливи- ми стимулами їх праці стають можливість здійснювати наукові дослідження та особисто обирати їх тематику, оплата участі у наукових заходах, забезпечення втілення знань чи залучення до управління. 3 огляду на це, виникає необхідність формування і розвитку сучасних методів стимулювання інноваційної активності працівників підприсмств, які забезпечили б належний рівень їх мотивування.

Матеріал і методи дослідження. Для розвитку процесів мотивування у зазначених умовах потрібно згадати про інноваційні методи стимулювання працівників через їх навчання та професійний і особистісний розвиток, до яких відносять коучінг, менторинг, баддинг, супервізію, едвайзинг тощо (Dauni, 2008; Pashkovska, 2016; Rosha, 2013; Sokolova, 2013). Розглянемо кожний із них. Згідно із визначенням М. Дауні, коучінг - це мистецтво сприяти підвищенню результативності, навчання і розвитку іншої людини (Dauni, 2008). У процесі коучінгової діяльності вирішують такі завдання: допомога у прийнятті працівниками рішень, оволодіння навиками самостійної діяльності; допомога менеджерам у роботі із працівниками, наділення їх рисами коуча; створення організації, яка здатна навчатись.

\section{Інформація про авторів:}

Дорошкевич Катерина Олегівна, канд. екон. наук, доцент, кафедра менеджменту і міжнародного підприємництва. Email: kateryna.o.doroshkevych@lpnu.ua

Вороновська Марта Миколаївна, канд. екон. наук, ст. викладач, кафедра менеджменту і міжнародного підприємництва. Email: marta_tomych@ukr.net

Салата Ігор Зеновійович, канд. екон. наук, ст. наук. співробітник, кафедра менеджменту і міжнародного підприємництва. Email: igor.zen9@yandex.ua

Цитування за ДСТУ: Дорошкевич К. О., Вороновська М. М., Салата І. З. Особливості менторингової діяльності на підприємствах в умовах інноваційного розвитку. Науковий вісник НлТУ України. Серія Економічна. 2018, т. 28, № 9. С. 44-48

Citation APA: Doroshkevych, K. O., Voronovska, M. M., \& Salata, I. Z. (2018). Features of mentoring enterprises activity in the innovative development conditions. Scientific Bulletin of UNFU, 28(9), 44-48. https://doi.org/10.15421/40280908

44 Науковий вісник НлтУ України, 2018, т. 28, № 9 Scientific Bulletin of UNFU, 2018, vol. 28, no 9 
Менторинг варто розглядати як один із методів навчання та розвитку персоналу (наставницьку діяльність), під час якого досвідченіший працівник ділиться знаннями зі своїми колегами протягом певного часу (Pashkovska, 2016). Його відмінність від коучінгу полягає у способах забезпечення процесу навчання та розвитку працівників. Менторинг передбачає допомогу, консультації та розроблення моделей поведінки для працівників (Rosha, 2013).

Подібними рисами володіє і едвайзинг, який полягає у залученні до процесу прийняття управлінських рішень порадника, консультанта, що користується, зазвичай практичному досвіду, запасом типових методів, пов'язаних 3 вирішенням часто повторюваних задач (Sokolova, 2013). Супервізія - це професійне консультування та аналізу як доцільності та якості використання практичних підходів і методів консультування, так і відносин, що виникають між клієнтом і консультантом, тобто один з методів теоретичного і практичного підвищення кваліфікації фахівців у сфері консультування (Oparina, 2011). В економічний літературі баддинг розглядають як неформальне наставництво (менторинг) або рівноправний коучінг. Під ним треба розуміти підтримку та допомогу співробітників одне одному задля досягнення особистих цілей та цілей підприємства (Shapiro, 2015). Цей перелік не $\epsilon$ вичерпним. У літературних джерелах можна знайти низку інших методів, призначених для навчання та розвитку персоналу підприємства, управління кадровим резервом.

Кожний із розглянутих методів мають переваги та недоліки та може бути впроваджений у практику мотиваційної діяльності вітчизняних підприємств в умовах інноваційного розвитку. Проте, порівняно з іншими методами, менторинг не потребує найму на роботу тренерів (коучів, т'юторів), адже ментором та менті є працівники підприємства. Метод також забезпечує персоналізоване навчання працівників, соціалізацію груп працівників різних національностей, віку, рівня освіти тощо, удосконалення мотиваційних процесів підприємства та зменшення плинності кадрів. Тому для розвитку інноваційної діяльності на підприємствах за допомогою засобів стимулювання інноваційної активності працівників зупинимось докладніше на особливостях менторингу.

Результати дослідження. Як уже зазначено, менторинг призначений для удосконалення роботи підприємства шляхом наставницької діяльності, під час якої досвідченіший працівник (ментор) ділиться знаннями зі своїми колегами протягом певного часу (менті). Отже, менторинг передбачає навчання одних працівників та нематеріальне стимулювання інших, що розглянемо ретельніше.

Менторингова діяльність на підприємстві необхідна, зважаючи на низку обставин. По-перше, кадровий склад багатьох підприємств характеризується значною кількістю працівників середнього віку. За допомогою менторингу на таких підприємствах будуть забезпечені умови для передачі знань і досвіду від старшого покоління молодому. По-друге, якщо якість середньої та вищої професійної освіти не відповідає вимогам ведення підприємницької діяльності, то така невідповідність може бути усунута у процесі менторингу, який також розглядають як метод персоналізованого навчання працівників підприємств. По-третє, позитивними зрушеннями у сфері управління персоналом багатьох підприємств $є$ впровадження і використання HR-систем. Оскільки наставництво є невід'ємною частиною таких системи, що передбачають роботу зі стажерами, управління кадровим резервом тощо, то менторингова діяльність $є$ необхідною для таких підприємств (Oparina, 2011).

Окрім цього, на багатьох підприємствах немає умов, які забезпечили б прозорість кар'єрного росту, розвиток персональних компетенцій, успішне подолання ризиків у професійній сфері тощо (Frolova, Bazarnova \& Goryacheva, 2017). У цьому контексті менторинг виконує функцію інструмента професійного розвитку працівників, нарощення їх особистісної зрілості шляхом удосконалення системи взаємовідносин у колективі та стимулювання. Як відомо, сучасні умови господарювання характеризуються зміною акцентів у веденні діяльності у бік вирішення завдань щодо забезпечення практичних умінь працівників співпрацювати з колегами, представниками інших підприємств та організацій тощо, удосконалення своїх потенційних професійних здібностей тощо (Saginov, 2016). Усі ці завдання вирішують у процесі менторингу.

У світовій практиці сформовано дві концептуальні моделі менторингу (наставництва): північноамериканська та європейська. Північноамериканська концепція наставництва має на меті таке. Старший за віком або більш професійний працівник (ментор) прагне допомогти молодому фахівцеві (менті). У межах цієї концепції на основі авторитету та шляхом застосування прямого впливу наставника (керівника) відбувається одностороннє навчання молодого фахівця через поради, спрямування його поведінки, переймання досвіду та отримання настанов.

Свропейська модель менторингу передбачає те, що наставник швидше володіє досвідом у тому чи іншому питанні, аніж наділений впливом на працівників. Ця модель передбачає побудову стосунків між учнем та наставником, що засновані на довірі. Вони забезпечують двосторонне навчання: наставник і учень навчаються один в одного, і їхні стосунки є взаємовигідними. Завдання наставника в цій моделі полягає у консультуванні учня. У європейській моделі безпосередній керівник не може бути наставником свого підлеглого. Проте керівник, зазвичай, $є$ учасником процесу навчання (Panfilova, 2016).

Незалежно від обраної моделі, застосування менторингу грунтується на принципах цілеспрямованості, конфіденційності, доступності і добровільності. Принцип цілеспрямованості говорить про те, що у процесі менторингу визначаються цілі, над досягненням яких ментор та менті будуть працювати разом. Конфіденційність визначає те, що уся інформація щодо цілей, завдань, ходу менторингової діяльності тощо залишається тільки між ментором і менті та не передається третім особам. Доступність передбачає можливість спілкування учасників менторингового процесу без обмежень, регламентованих часом їх зустрічей. Добровільність менторингу забезпечує ймовірність завершити спільну роботу в будь-який час. Якщо взаємодія між сторонами є неефективною, то існує можливість замінити ментора (Dolgopolova \& Anikina, 2015).

Застосування менторингу на підприємствах повинно відбуватись згідно 3 певним порядком: діагностика проблеми, формування плану роботи; спостереження за роботою менті; робота у співпраці; самостійна діяль- 
ність менті; професійне обговорення результатів та забезпечення зворотного зв'язку (Belousov, 2013). У процесі планування потрібно окреслити цілі менторингової діяльності, завдання із іiі реалізації, сформувати бюджет, забезпечити комунікаційні зв'язки тощо. Цілями менторингової діяльності переважно є: зниження плинності кадрів на підприємствах; підвищення рівня лояльності працівників та їх відданості підприємству; підвищення результативності роботи працівників під керівництвом менторів; покращення міжособистійної взаємодії; швидша адаптація нових фахівців на робочому місці тощо (Brusenko, 2014).

Для успішного впровадження менторингу на підприємстві потрібно застосовувати інтегрований підхід, що передбачає ретельне аналізування діяльності підприємства, ідентифікацію проблем у сфері управління персоналом, підготовку всіх необхідних документів, які регулюють загальний процес менторингу (наставництва). Також потрібно сформувати комплексну систему стимулювання для наставників, яка буде містити перелік усіх матеріальних та нематеріальних благ від їх участі у процесі менторингу (Rekun, Baboshko \& Bushlya, 2015).

Обговорення отриманих результатів. Від дослідження технології менторингу перейдемо до його особливостей. Менторинг - це тривалий і комплексний процес, що потребує певних часових ресурсів. Якщо підприємство не володіє достатніми часовими ресурсами для забезпечення процесу менторингу, то його результативність буде низькою. Іноді варто передбачити застосування менторингу у тестовому режимі. Менторингова діяльність повинна також бути гнучкою, під час іiі застосування потрібно усунути бюрократичні процедури, які ще збільшать час на впровадження цього методу.

Менторинг майже завжди складається 3 періодів емоційного підйому та моментів втоми і часткової демотивації. Це варто врахувати під час складання плану менторингової роботи (Ivanik, 2015).

Для успішного впровадження менторингу у діяльність підприємства потрібно ретельно підійти до питання вибору ментора. Ментором повинен стати працівник, який не обтяжений поточними обов'язками та може узяти на себе додаткову роботу.

Особливим $\epsilon$ також результат менторингової діяльності, який полягає не лише в отриманні знань, умінь i навиків працівником, а також у їх впровадженні в практичну діяльність підприємства із забезпеченням певної результативності. Водночас у процесі менторингової діяльності відбувається навчання обох сторін процесу, формуються особистісні взаємозв'язки між ними, особиста прихильність тощо (Sundukova \& Vanykina, 2016). Зі сторони ментора, окрім матеріального, також виникає нематеріальне мотивування шляхом посилення авторитету та статусу у команді, залучення до управління, реалізації власного потенціалу тощо (Prytula \& Levchenko, 2013).

На основі наведеного вище матеріалу, узагальнимо особливості менторингової діяльності за трьома групами: особливості процесу менторингу (процесійні), особливості результатів менторингової діяльності, методологічні особливості (рисунок).
Особливості менторингової діяльності на підприємстві

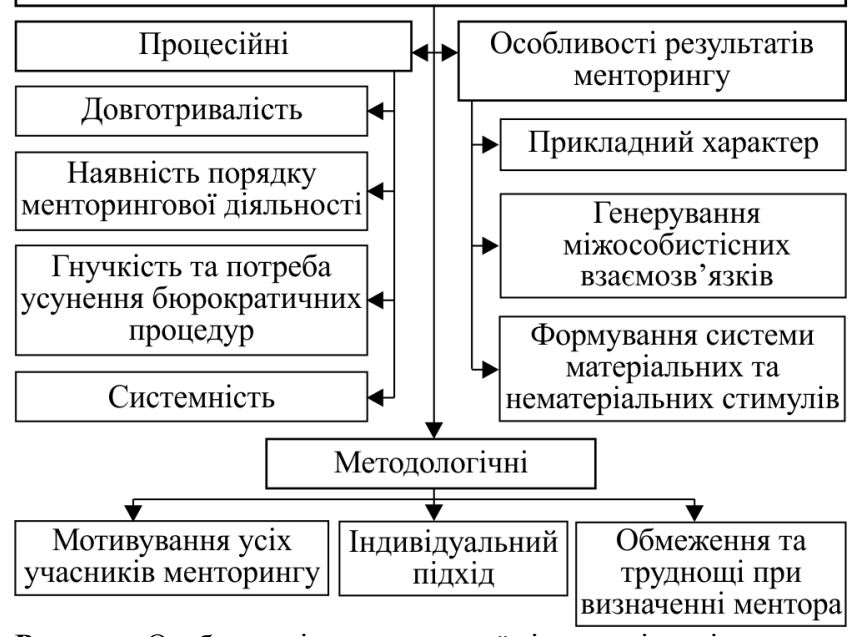

Рисунок. Особливості менторингової діяльності на підприємстві

До першої групи процесійних особливостей віднесемо:

- наявність порядку менторингової діяльності, який складається із чітко визначених етапів щодо ії реалізації;

- довготривалість процесів впровадження і використання менторингу, що іноді супроводжується тестовим режимом використання;

- гнучкість та рекомендації щодо усунення бюрократичних процедур, які збільшують тривалість впровадження менторингу;

- системність, що передбачає аналізування діяльності підприємства, ідентифікацію проблем у сфері управління персоналом, підготовку документів, а лише потім впровадження менторингу тощо.

Особливості результатів менторингової діяльності полягають у їх прикладному характері (усі утримані менті знання застосовуються у практичні діяльності на підприємстві), забезпеченні особистої зацікавленості та прихильності учасників менторингу (генерування міжособистісних взаємозв'язків), формуванні системи матеріальних та нематеріальних стимулів (ментор та менті окрім матеріальної винагороди отримують нематеріальні стимули шляхом авторитету, набуття знань, залучення до управління тощо).

Як методологічні властивості менторингу вкажемо на обмеження та труднощі у визначенні ментора; індивідуальний підхід, що передбачає роботу ментора та менті у парі; мотивування усіх учасників менторингової діяльності (ментора, який набуває авторитету і матеріальної винагороди та менті, що навчається у процесі трудової діяльності) тощо.

Висновки. У сучасних умовах господарювання, які супроводжуються інноваційною активністю підприємств, відбувається розвиток мотиваційних процесів. Усталені методи матеріального стимулювання праці перестають бути результативними та не сприяють творчій креативній діяльності працівників. Для вирішення цього питання на підприємствах потрібно впроваджувати методи навчання, професійного та особистісного розвитку працівників, до яких відносять коучінг, менторинг, баддинг, супервізію, едвайзинг тощо. Менторинг як наставницька діяльність, під час якої більш досвідчений працівник (ментор) ділиться знаннями зі своїми колегами протягом певного часу (менті), 
порівняно з іншими методами, не потребує найму на роботу тренерів та володіє низкою інших переваг.

Особливості менторингової діяльності на підприємствах в умовах інноваційного розвитку поділено на три групи: процесійні особливості (довготривалість, наявність порядку менторингової діяльності, гнучкість та необхідність усунення бюрократичних процедур, системність), особливості результатів менторингової діяльності (прикладний характер, генерування міжособистісних взаємозв'язків, формування системи матеріальних та нематеріальних стимулів), методологічні особливості (мотивування усіх учасників менторингу, індивідуальний підхід, обмеження та труднощі при визначенні ментора).

У подальших дослідженнях за проблемою доцільно дослідити чинники, що визначають менторингову діяльність підприємств в умовах інноваційного розвитку.

\section{Перелік використаних джерел}

Belousov, M. (2013). Mentoryi ot informatsionnyih tehnologiy. Biznes-zhurnal, 4, 15-16. [In Russian].

Brusenko, N. V. (2014). Rozrobka programy mentoryngu na pidpryyemstvi: osnovni skladovi. Visnyk Cherniveczkogo torgovelno-ekonomichnogo instytutu. Ekonomichni nauky, 1, 195-202. Retrieved from: http://nbuv.gov.ua/UJRN/Vchtei 201412 27. [In Ukrainian].

Dauni, M. (2008). Effektivnyiy kouching: uroki koucha kouchey. Moscow: Dobraya kniga, 288 p. [In Russian].

Dolgopolova, V., \& Anikina, E. (2015). Nastavnichestvo: na AO "SHK" poyavyatsya mentoryi. Upravlenie proizvodstvom. Retrieved from: http://www.up-pro.ru/library/personnel management/training/nastavnichestvo-shk.html. [In Russian].

Frolova, S. V., Bazarnova, N. D., \& Goryacheva, N. A. (2017). Korporativnyiy mentoring kak instrument professionalnogo rosta molodogo spetsialista. Gosudarstvennyiy Sovetnik, 4, 45-49. [In Russian].

Ivanik, O. (2015). Rivnyj rivnomu. Kyiv: Insha osvita, 57 p. [In Ukrainian].

Kuzmin, O. Ye., \& Melnyk, O. G. (2003). Osnovy menedzhmentu. Kyiv: Akademvydav, 416 p. [In Ukrainian].

Oparina, N. N. (2011). Sovremennyie metodyi razvitiya kadrovogo rezerva: Materialy IX Mizhnarodnoyi konferentsiyi fakulteta gosudarstvennogo upravleniya MGU im. M. V. Lomonosova "Gosudarstvennoe upravlenie v XXI veke". (pp. 278-287). [In Russian].

Panfilova, A. P. (2016). Nastavnichestvo i obuchenie na rabochem meste: terminologicheskiy analiz zarubezhnyih metodov. Sovremennyie tehnologii upravleniya, 12(72). Retrieved from: https://sovman.ru/article/7202/. [In Russian].

Pashkovska, T. (2016). Mentoring \& soaching: meta, perevagy, rezultaty. Yurydychna gazeta. Retrieved from: http://yur-gazeta.com/publications/actual/mentoring--soaching-meta-perevagi-rezultati.html. [In Ukrainian].

Rekun, G., Baboshko, A., \& Bushlya, D. (2015). Mentoring as an effective method of professional development and personnel training. Problemy i perspektyvy rozvytku pidpryyemnycztva, 3(10), 54-59. [In Ukrainian].

Rosha, A. (2013). The Similarities and Differences between Coaching and Other Targeted Interventions. Information Systems Management Institute, 24, 119-126.

Saginov, K. M. (2016). Mentoring v professionalnom razvitii pedagogov: teoriya i praktika. Astana: AOO "Nazarbaev Intellektualnyie shkolyi" Tsentr pedagogicheskogo masterstva, 84 p. [In Russian].

Shapiro, S. A., \& Potapova, E. A. (2015) Sovershenstvovanie professionalnyih kompetentsiy kak faktor povyisheniya effektivnosti truda rabotnikov kommercheskih bankov. Moskva - Berlin: Direkt-Media. 153 p. [In Russian].

Sokolova, E. I. (2013). Analiz teorminologicheskogo ryada "Kouch", "Mentor", "Tyutor", "Fasilitator", "Edvayzer" v kontekste nepreryivnogo obrazovaniya Nauchnyiy elektronnyiy ezhekvartalnyiy zhurnal. Nauchnyiy elektronnyiy ezhekvartalnyiy zhurnal nepreryivnoe obrazovanie: XXI vek, 4. Retrieved from: https://1l121.petrsu.ru/journal/article.php?id=2086. [In Russian].

Sundukova, T. O., \& Vanyikina, G. V. (2016). Kouching, mentoring i edvayzing: traditsii i innovatsii. Sovremennaya pedagogika, 11. Retrieved from: http://pedagogika.snauka.ru/2016/11/6217. [In Russian].

К. О. Дорошкевич1, М. М. Вороновская ${ }^{1}$, И. 3. Салата ${ }^{2}$

${ }^{1}$ Начиональный университет "Львовская политехника", г. Львов, Украина ${ }^{2}$ Национальная академия сухопутных войск им. гетмана Петра Сагайдачного, г. Львов, Украина

\title{
ОСОБЕННОСТИ МЕНТОРИНГОВОЙ ДЕЯТЕЛЬНОСТИ НА ПРЕДПРИЯТИЯХ
} В УСЛОВИЯХ ИННОВАЦИОННОГО РАЗВИТИЯ

\begin{abstract}
Исследованы мотивационные процессы предприятий в условиях инновационного развития, которые заключаются в стимулировании творческой активности, креативности работников и преобладании нематериальных методов стимулирования над материальными; определено влияние персонализированных методов обучения и развития персонала на инновационную деятельность предприятий. Исследованы методы стимулирования работников за их обучение и профессиональное и личностное развитие: коучинг, менторинг, баддинг, супервизия, эдвайзинг и т. п. Учитывая преимущества и недостатки исследованных методов, в практику мотивационной деятельности рекомендовано внедрение менторинга как наставнической деятельности, во время которого более опытный работник делится знаниями со своими коллегами в течение определенного времени. Особенности менторинговой деятельности на предприятиях в условиях инновационного развития разделены на три группы: процессные особенности, характеризующие процесс менторинговой деятельности (продолжительность, наличие порядка менторинговой деятельности, гибкость и необходимость устранения бюрократических процедур, системность); особенности результатов менторинговой деятельности (прикладной характер, генерирование межличностных взаимосвязей, формирование системы материальных и нематериальных стимулов); методологические особенности (мотивирование всех участников менторинга, индивидуальный подход, ограничения и трудности при определении ментора).
\end{abstract}

Ключевые слова: мотивация; инновационная деятельность; наставничество; коучинг.

\section{K. O. Doroshkevych', M. M. Voronovska', I. Z. Salata ${ }^{2}$ \\ ${ }^{1}$ Lviv Polytechnic National University, Lviv, Ukraine ${ }^{2}$ Hetman Petro Sahaidachnyi National Army Academy, Lviv, Ukraine \\ FEATURES OF MENTORING ENTERPRISES ACTIVITY IN THE INNOVATIVE DEVELOPMENT CONDITIONS}

The authors have investigated the motivation processes (the process of inducing employees to achieve the goals of the organization) of the enterprises in the conditions of innovative development, which consist in stimulation of creative activity, employees creativity and predominance of nonmaterial methods of stimulation over material. The influence of personalized teaching methods and per- 
sonnel development on innovative activity of enterprises is outlined. The following methods of stimulation of employees through their training and professional and personal development are studied: coaching, mentoring, budding, supervising, advising, etc. Concerning the advantages and disadvantages of the investigated methods, in the practice of motivational activity we recommend the introduction of mentoring activity, when a more experienced employee shares knowledge with his colleagues over a period of time. We have also examined the models of mentoring activity (North American and European), principles (purposefulness, confidentiality, accessibility and voluntariness.) and conditions of its effective application at enterprises. The features of mentoring activity in enterprises under the conditions of innovative development are divided into three groups: processional features that characterize the process of mentoring activity (long-term, presence of the order of mentoring activity, flexibility and necessity of eliminating bureaucratic procedures, systemic as a process of analyzing enterprise activity, identifying problems in the field of personnel management, preparing documents, and only then introducing mentoring), features of the results of mentoring activity (applied character, generation of interpersonal interconnections, the formation of the system of material and non-material incentives), methodological features (individual approach that involves the work of mentors and mentee in a pair; motivating all participants in mentoring activities (mentor who acquires authority and material reward and mentee trained in the process of labour activity)).

Keywords: motivation; innovative activity; mentoring; coaching. 